\title{
On the Safe Use of Portable Intraoral X-ray Units in Large-Scale Disasters
}

\author{
YUSEI OTAKA*, YASUO HARATA*, MAKI IZAWA*, \\ ATSUSHI IWAWAKI**, RURI ASAMI**, HIDEKI SAKA**,*** \\ AND YASUHIKO OKUMURA*
}
大規模災害時における携帯型口内法 X 線撮影装置の安全使用について

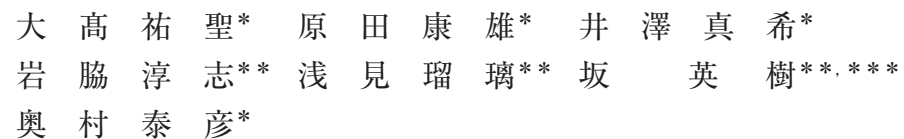

要約 : 目的 : 東日本大震災での身元確認や在宅医療での需要拡大から, 現在多くの携帯型口内法 X 線撮影装置が製造販売され ている。しかし，携帯型口内法 X 線撮影装置の報告は少ない。そこで, 今回バッテリ駆動が可能な 3 台の携帯型口内法 X 線撮影 装置の出力特性と空中線量を測定し, 安全に使用するための防護について考察した。

材料と方法 : 空中線量の測定には, 携帯型口内法 X 線撮影装置としてデキシコ ADX4000, デキシコ ADX4000W およびデキシ コ DX3000（10DR JAPAN 社），被写体として IEC 規格 CT 線量測定用頭部ファントム（PMMA 製円柱直径 $16 \mathrm{~cm} \times$ 高さ $15 \mathrm{~cm} ）$ を用い, 線量計 Pitman 37D と付属の 350cc 電離箱（Pitman 社）を用いた。

結果 : 操作者の作業領域を $0.5 \mathrm{~m}$ 位置で $180 \pm 60^{\circ}$ の扇形範囲内とすると, 平均空中線量は各装置のコーン先端 $1 \mathrm{mGy}$ あたり $\mathrm{ADX} 4000$ では $0.353 \mu \mathrm{Gy}, \mathrm{ADX} 4000 \mathrm{~W}$ では $0.297 \mu \mathrm{Gy}, \mathrm{DX} 3000$ では $0.288 \mu \mathrm{Gy}$ であった。

考察：大規模災害発生時の身元確認業務では 1 日あたりに撮影する回数が多いため, すべての機種で管理区域の設定, 被写体 からの距離を充分に取る，防護衣や衝立を利用する等の防護策を取って線量限度を超えないように利用すべきである。

Abstract : Objective: The needs of intraoral radiography are increasing for home care and especially for victim identification after the Great East Japan Earthquake. In this study, we evaluated the characteristics of output X-rays and measured air kermas of stray radiation from three battery-powered portable intraoral X-ray units.

Materials and Methods: The air kermas of stray radiation, generated from an IEC CT dosimetry head phantom and the X-ray units, which included DEXICO ADX4000, DEXICO ADX4000W, and DEXICO DX3000 (10DR Japan), were measured using Pitman 37D and the 350cc ionization chamber attached (Pitman).

Results: If an operator works in a sectioned area with a central angle of $180 \pm 60$ degrees and a radius of $0.5 \mathrm{~m}$, the mean stray radiation was $0.353 \mu \mathrm{Gy}$ for the ADX4000, $0.297 \mu \mathrm{Gy}$ for the ADX4000W, and $0.288 \mu \mathrm{Gy}$ for the DX3000 per $1 \mathrm{mGy}$ at the cone tip of each unit.

Discussion: In the event of a large-scale disaster, an operator would be taking many radiographs for victim identification each day. Therefore, this can be done by setting up a control area that ensures a sufficient distance from the radiation source, wearing a lead apron and using a protection board.

Key words : portable intraoral X-ray units（携帯型口内法 X 線撮影装置）, stray radiation（迷放射線）, radiological protection (放射線防護), large-scale disasters (大規模災害)

〔Received Feb. 15, 2017〕

\footnotetext{
* Division of Dental Radiology, Department of Diagnostic \& Therapeutic Sciences, Meikai University School of Dentistry (Chief: Prof. YasuHiko OKUMURA) 1-1 Keyakidai, Sakado, Saitama 350-0283, Japan.

** Division of Forensic Odontology, Department of Diagnostic \& Therapeutic Sciences, Meikai University School of Dentistry (Chief: Prof. HidEKI SAKA)

*** Forensic Odontology Center, Meikai University School of Dentistry (Chief: Prof. HIDEKI SAKA)

* 明海大学歯学部病態診断治療学講座歯科放射線学分野 (主任 : 奥村泰彦教授)

** 明海大学歯学部病態診断治療学講座歯科法医学分野 (主任 : 坂 英樹教授)

*** 明海大学歯学部歯科法医学センター（主任：坂 英樹教授）
} 


\section{Introduction}

Intraoral radiography findings were frequently used for victim identification after the Great East Japan Earthquake. Because of the difficulties in securing a stable power supply at the time of such a disaster, batterypowered portable intraoral X-ray units were particularly useful. Now, Japanese society is super-aging and the need for home health care is increasing rapidly. The manufacturers produce and market various types of portable intraoral X-ray units. However, with regard to radiation protection, there are new problems of portable intraoral X-ray units $^{1-6)}$ compared with well-known conventional intraoral X-ray units ${ }^{7-14}$. In the event of a largescale disaster, intraoral radiography for victim identification will be conducted more frequently than routine intraoral radiography. At the time of the disaster, equipment and resources may be limited and minimum attention may be directed to the operators' and general public risk of exposure to radiation.

This study was conducted to examine the safe use of portable intraoral X-ray units for victim identification in a time of large-scale disasters. Three commercially available battery-powered portable intraoral X-ray units were evaluated in terms of their output X-rays during intraoral radiography. In our investigation of these three units, intraoral X-ray film and digital X-ray sensors were used to take radiographs of the phantom of mandibular molars, and on the basis of their output X-rays, the optimum exposure factors for diagnostic examination were determined. The air kerma distribution of stray radiation around the head phantom during intraoral radiography was analyzed. We consider the exposure factors of the three units and discuss protective measures for the safe handling of these units.

\section{Materials and Methods}

\section{Materials}

The portable intraoral X-ray units subjected to the present study included the DEXICO ADX4000 (ADX4000) and DEXICO ADX4000W (ADX4000W) which have digital X-ray sensors attached to the main bodies and enable confirmation of images immediately after X-ray exposure, and the DEXICO DX3000 (DX3000), which has no digital X-ray sensor attached to the main body (Fig. 1, Table 1, 2).

To determine the dose for obtaining optimum diagnostic images, we prepared the phantom of the right mandible for visual evaluation of images (Fig. 2a). This phantom was prepared by burying a canine mandible to the mandibular ramus and the aluminum steps shown in Fig. $2 \mathrm{~b}$ $(7 \mathrm{~mm}$ vertical $\times 20 \mathrm{~mm}$ horizontal $\times 10 \mathrm{~mm}$ high, width of step $2 \mathrm{~mm}$, interval of height $1 \mathrm{~mm}$, a total of 10 steps) in epoxy resin. The external size of the resin, which was similar to the soft tissue, was $25 \mathrm{~mm}$ thick $\times 70 \mathrm{~mm}$ high $\times 100 \mathrm{~mm}$ wide.

We used an IEC CT dosimetry head phantom $(\mathrm{a} 16 \mathrm{~cm}$ diameter $\times 15 \mathrm{~cm}$ height PMMA cylinder) (Fig. 2c), which was similar to the head subjected to intraoral radiography.

The materials and devices used in this study are listed in Table 1 and their photos are shown in Fig. 1, 2, 3.

\section{Methods}

1) Measurement of Output X-rays from the Portable Intraoral X-ray Units

A round mark on ThinX RAD (Fig. 3a) was placed in

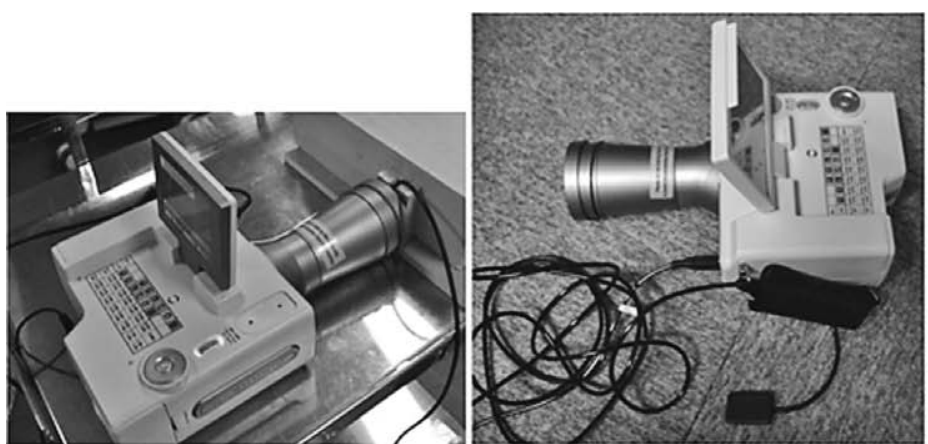

a : DEXICO ADX4000 b : DEXICO ADX4000W

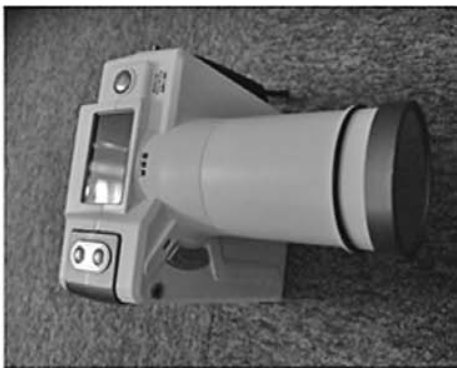

c : DEXICO DX3000

Fig. 1 Portable intraoral X-ray units with digital X-ray sensors DEXICO ADX4000 (a) and DEXICO ADX4000W (b), and DEXICO DX3000 without sensors (c). 
Table 1 Material

\begin{tabular}{|c|c|c|c|}
\hline Apparatus and Material & Models & Manufacturer & Reference \\
\hline Portable Intraoral X-ray Unit & $\begin{array}{l}\text { DEXICO ADX4000 (with CCD) } \\
\text { DEXICO ADX4000W (with CMOS) } \\
\text { DEXICO DX3000 }\end{array}$ & 10DR JAPAN & $\begin{array}{l}\text { Fig. 1a } \\
\text { Fig. 1b } \\
\text { Fig. 1c }\end{array}$ \\
\hline Mandible Phantom & Mandy No.1 (a mandible part phantom) & Homemade & Fig. 2a, b \\
\hline Head Phantom & IEC CT dosimetry head phantom & Qualita & Fig. 2c \\
\hline X-ray Film & $\begin{array}{l}\text { HR-S } \\
\text { InSight }\end{array}$ & $\begin{array}{l}\text { Fujifilm } \\
\text { Carestream Health }\end{array}$ & \\
\hline Digital X-ray Sensor & RVG6100 (CMOS) & Carestream Health & \\
\hline Automatic Film Processor & 810Plus & Dent-X & \\
\hline Densitometer & TR-524AMD & Macbeth & \\
\hline Film Scanner & GT-X820 & EPSON & \\
\hline Multi-functional X-ray Detector & $\begin{array}{l}\text { ThinX RAD } \\
\text { Xi }\end{array}$ & RaySafe & Fig. 3a \\
\hline Dosemeter & Pitman 37D (350-cc ionization chamber) & Pitman & Fig. 3b \\
\hline Liquid Crystal Display & FlexScan EV2116W & EIZO & \\
\hline Image Processing Program & ImageJ 1.46r; Java1.6.0_65 (64-bit) & $\mathrm{NIH}$ & \\
\hline
\end{tabular}

Table 2 Specifications of the Portable Intraoral X-ray Units (DEXICO series)

\begin{tabular}{lccc}
\hline \multicolumn{1}{c}{ Model } & ADX4000 & ADX4000W & DX3000 \\
\hline Tube Voltage & $60 \mathrm{kV}$ & $60 \mathrm{kV}$ & $60 \mathrm{kV}$ \\
Tube Current & $1 \mathrm{~mA}$ & $2 \mathrm{~mA}$ & $2 \mathrm{~mA}$ \\
X-ray Tube & D-081B (Toshiba) & D-081B (Toshiba) & D-081B (Toshiba) \\
Focal Spot Size & $0.8 \mathrm{~mm}$ & $0.8 \mathrm{~mm}$ & $0.8 \mathrm{~mm}$ \\
Total Filtration & $1.5 \mathrm{mmAl} \mathrm{eq.}$ & $1.5 \mathrm{mmAl} \mathrm{eq.}$ & $1.5 \mathrm{mmAl} \mathrm{eq.}$ \\
Exposure Time & $0.05 \sim 1.35 \mathrm{~s}$ & $0.05 \sim 1.35 \mathrm{~s}$ & $0.05 \sim 1.35 \mathrm{~s}$ \\
Focus Cone Tip Distance & $>15 \mathrm{~cm}$ & $>15 \mathrm{~cm}$ & $>15 \mathrm{~cm}$ \\
Field Size & $60 \mathrm{~mm}$ (diameter) & $60 \mathrm{~mm}$ (diameter) & $60 \mathrm{~mm}$ (diameter) \\
\hline
\end{tabular}

the center of the X-ray field in such a way that it remained in contact with the cone tip of a portable intraoral X-ray unit (Fig. 4). The central X-ray was then measured in terms of the following parameters: air kerma in free air (hereinafter referred to as "cone tip dose"), tube voltage, air kerma rate, aluminum half-value layer and exposure time. In this manner, the output Xray characteristics at the cone tip of three units were analyzed. Because ThinX RAD cannot be used for measurement under some exposure conditions, Xi was used to measure these parameters under these conditions. The specifications of the units used are listed in Table 2.

2) X-ray Field Size Measurement of the Portable Intraoral X-ray Units
To measure the $\mathrm{X}$-ray field size at the cone tip, $8 \times 10$ inches HR-S film and cassette $(203 \times 254 \mathrm{~mm})$ without an intensifying screen were used. The cassette was set to keep contact with the cone tip. The cone tip doses were adjusted to the following levels for the respective units: ADX4000 (0.0 [unexposed], 0.5, 1.0, 2.7mGy), ADX4000W (0.5, 1.0, 1.5, 5.4mGy), and DX3000 (0.5, 1.0, 1.5, 5.8mGy). X-ray irradiated four parts of each film. The irradiated film was developed under the following conditions: 810 Plus, $27.7^{\circ} \mathrm{C}, 4$ minutes and 27 seconds. The optical density at the center of the X-ray field of each film was measured using TR-524AMD. Within the range where the linear relationship between the cone tip dose and the optical density could be observed, X-ray field images 


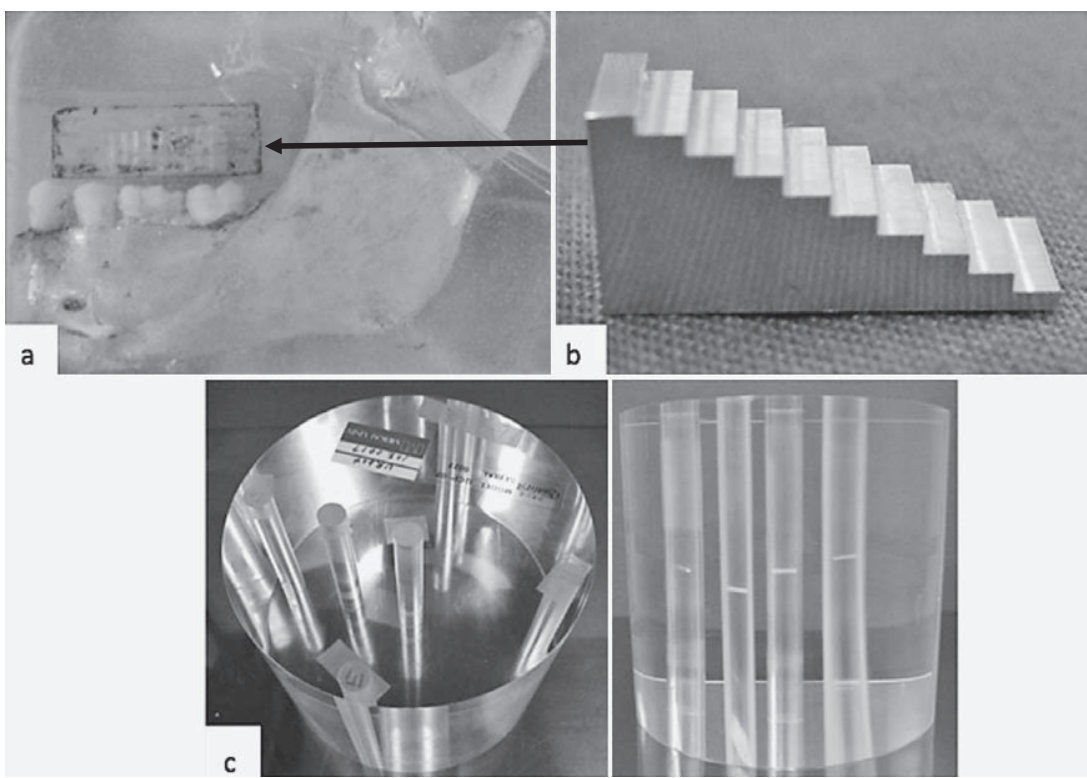

Fig. 2 A phantom of a mandible (a) including an aluminum step wedge (b) with a thickness from $1 \mathrm{~mm}$ to $10 \mathrm{~mm}$ with interval of $1 \mathrm{~mm}$, and an IEC head phantom (c), which is a PMMA cylinder with a 16-cm diameter $\times$ 15 -cm height.
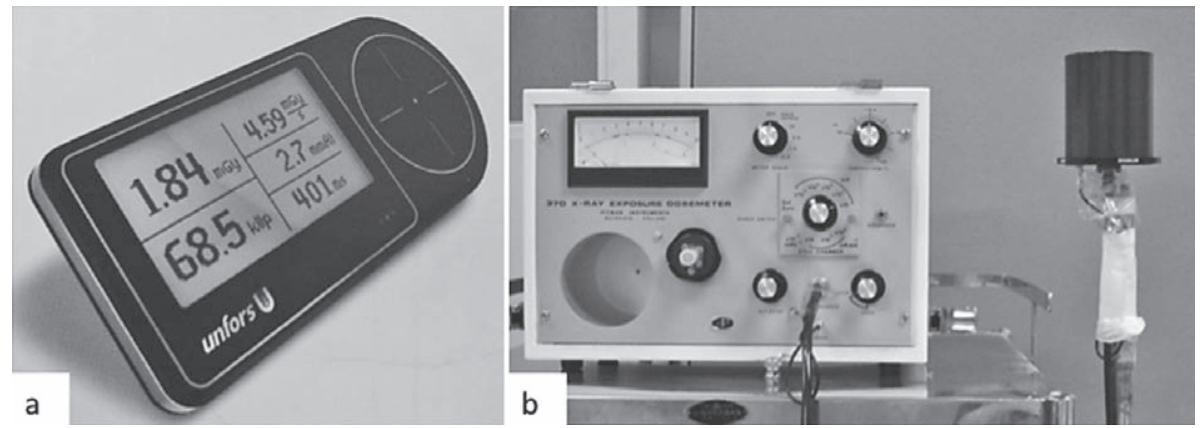

Fig. 3 A multi-parameter X-ray detector of ThinX RAD (a), which is the instrument for simultaneous measurement of dose, dose rate, $\mathrm{kVp}$, HVL, exposure time and pulses, and X-ray dosemeter Pitman 37D, with an ionization chamber of 350cc (b).

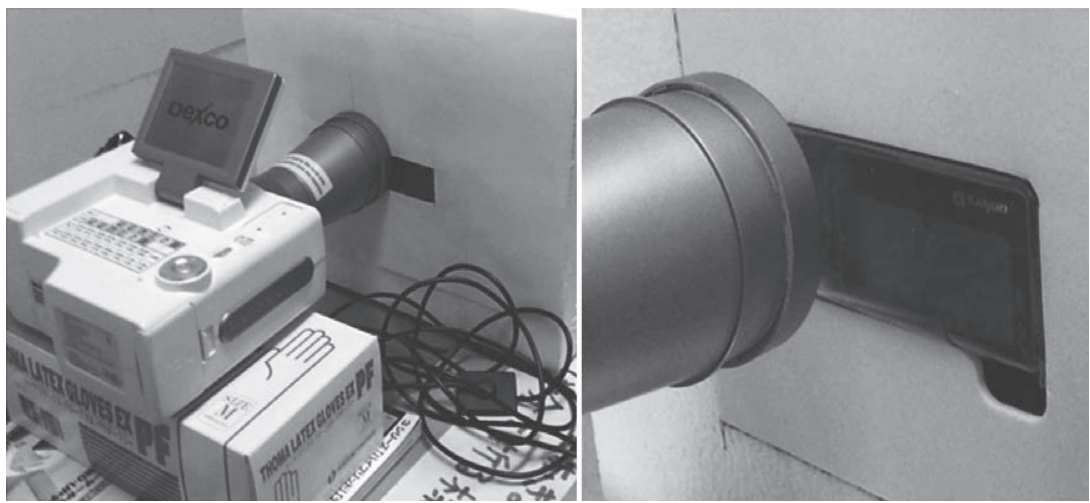

Fig. 4 Measurement of multi-parameters of the output X-rays at a cone-tip of a portable intraoral X-ray unit using ThinX RAD. 


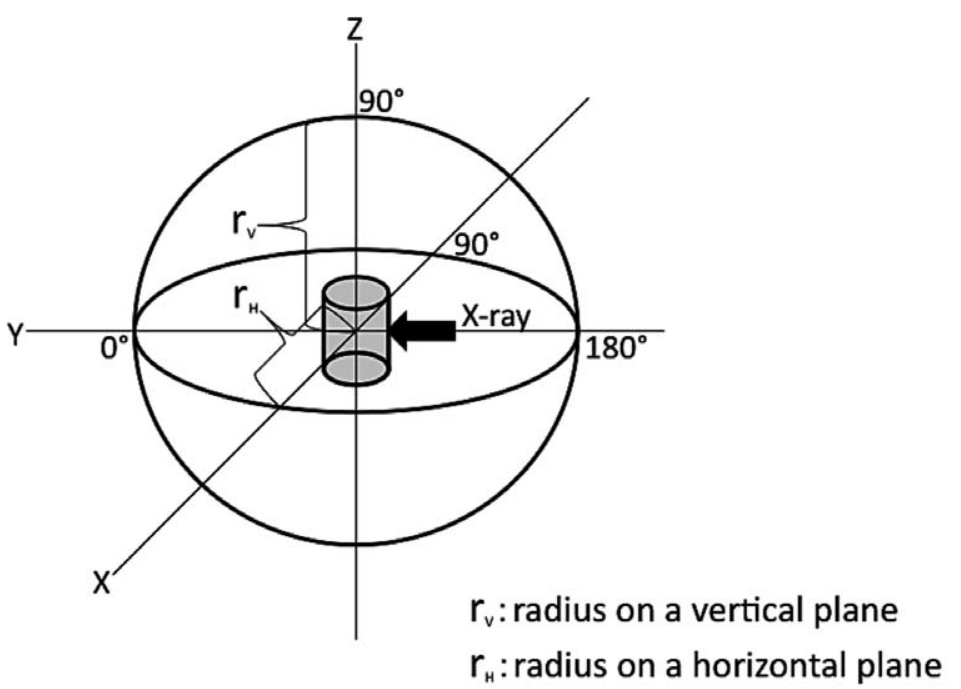

Fig. 5 Experimental setup for the measurement of stray radiation scattered from a PMMA cylindrical head phantom $(16-\mathrm{cm}$ diameter $\times 15$-cm height) in intraoral radiography.

X-ray beam indicated as the arrows of a symbol ( $)$ in Fig. 5.

with an optical density that did not exceed one were selected. These images were scanned using GT-X820. Using ImageJ, the diameter to the margin having a quarter of the pixel value at the center of the X-ray field was measured in the following two directions: one direction perpendicular to the axis of an X-ray tube and the other direction parallel to the axis. The diameter of the X-ray field size was determined according to the mean of these two measurements.

3) Measurement of Doses for Radiography Using the Mandibular Phantom

The positioning for radiography of the mandibular phantom was determined in the following manner. The phantom was kept in contact with the cone tip so that the site of crown-crown contact between the mandibular second premolar and first molar would be in the center of image. InSight film or a digital X-ray sensor attached to the unit was used for radiography according to the paralleling technique. Because the DX3000 does not have a digital X-ray sensor, the RVG6100 was used for radiography. InSight film could be processed according to the technique for development of HR-S film.

Dental radiologists certified by the Japanese Society for Oral and Maxillofacial Radiology (JSOMR) and employed by the Division of Dental Radiology, Department of Diagnostic and Therapeutic Sciences, Meikai University School of Dentistry, examined the images obtained at various cone tip doses and determined whether they might serve well for making a diagnosis. Using the same film viewers, they observed the film images under consistent lighting conditions. A FlexScan EV2116W was used to observe the digital images saved in BMP format. In this experiment, the subjects were asked to observe a series of images obtained at various cone tip doses and select the optimum images for making a diagnosis. In this manner, the optimum cone tip doses for making a diagnosis were determined.

4) Measurement of Stray Radiation Around the Head Phantom

An IEC CT dosimetry head phantom (Fig. 2c) was used to simulate intraoral radiography and stray radiation around the phantom was measured with a Pitman 37D and an attached 350cc ionization chamber (hereinafter referred to as "air kerma", which means the air kerma in free air of stray radiation measured). The geometric arrangement for measurement is illustrated in Fig. 5. As the origin of the coordination system, the center of the cylindrical phantom was set at a height of $1.0 \mathrm{~m}$ from the floor and the central axis of the cylinder was brought vertically in line with the $\mathrm{z}$-axis of the coordination system. The focal spot of the X-ray unit and the geometric center of the ionization chamber for measurement of the air kerma were positioned at the same height of $1.0 \mathrm{~m}$. The cone tip of the X-ray unit was kept in contact with the phantom surface and the central Xray was directed toward the origin. On the xy-plane 
parallel to the floor surface that was perpendicular to the $z$-axis and passed through the origin, two circles with radii from the center of the phantom of $0.5 \mathrm{~m}$ and $1.0 \mathrm{~m}$ were made. On each circumference of the circle, a central X-ray direction was set at zero degrees and a total of 24 points at intervals of 15 degrees in a clockwise direction, from zero degree to 360 degrees, was determined for the measurement of air kerma in the horizontal direction for exposure time of $1 \mathrm{~s}$ with each X-ray unit.

For the measurement of air kerma in the vertical direction, the positioning as illustrated in Fig. 5 was adopted. The phantom and the X-ray unit were rotated by 90 degrees, from the $\mathrm{z}$-axis to the $\mathrm{x}$-axis. The rotated yz-plane was then regarded as the plane perpendicular to the floor surface. A measurement method in a horizontal direction was used under these conditions.

We measured for air kerma once we had confirmed the high reproducibility of the results of measurement for exposure time of $1 \mathrm{~s}$ with each X-ray unit. Because the point corresponding to zero degrees overlapped the point corresponding to 360 degrees, a total of four measurement values in the horizontal and vertical directions were obtained. At the points corresponding to 180 degrees, two measurement values in the two directions were obtained. We checked the measurement accuracy and confirmed that the influence of stray radiation from the floor was negligible. The air kerma value in $\mu \mathrm{Gy}$ was converted from measured exposure value in $\mathrm{C} / \mathrm{kg}$

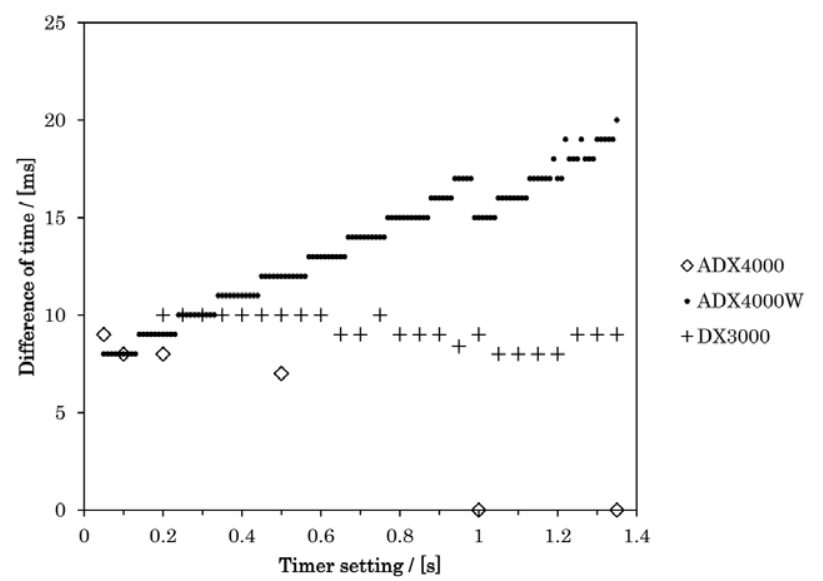

Fig. 6 Exposure time differences between timer settings and measured exposure times for portable intraoral X-ray units (ADX4000, ADX4000W, and DX3000*) *Timer difference was measured using Xi (RaySafe) above $1 \mathrm{~s}$. (or R) using $8.73 \times 10^{3} \mu \mathrm{Gy} / \mathrm{R}$. Then, the converted air kerma value was divided by the cone tip dose (mGy) for exposure time of $1 \mathrm{~s}$ with each X-ray unit for normalization $(\mu \mathrm{Gy} / \mathrm{mGy})$.

\section{Results}

1. Output Characteristics of the Portable Intraoral Xray Units

The output X-ray characteristics of the ADX4000, ADX4000W and DX3000 units were measured and the results are shown in Fig. 6-10. The timer-controlled exposure time of the three units also were measured. In the event the timer was set at less than $0.1 \mathrm{~s}$, exposure time was shorter than timer settings and the difference was $10 \mathrm{~ms}(10 \%)$ in any of the three units. For a timer setting from 0.1 to $1.35 \mathrm{~s}$, exposure time was shorter than timer settings and the difference was $20 \mathrm{~ms}$. These results were compared with the values set for the three units (Fig. 6). The cone tip dose was proportional to the manufacturer's nominal value of tube current-exposure time product (mAs value). For the least-square regression lines of the three units, the ADX4000 and ADX4000W showed the same results, $2.01 \mathrm{mGy} / \mathrm{mAs}$, while the DX3000 showed $2.29 \mathrm{mGy} / \mathrm{mAs}$ (Fig. 7). For the cone-tip dose rates, the ADX4000 and ADX4000W showed twofold different values in proportion to tube currents of $1 \mathrm{~mA}$ and $2 \mathrm{~mA}$. In the event that the timer was set at less than 0.1 s, all three units showed a downward trend of dose rates (Fig. 8).

At any timer setting, the tube voltages of the DX3000 and ADX4000W showed the manufacturer's nominal

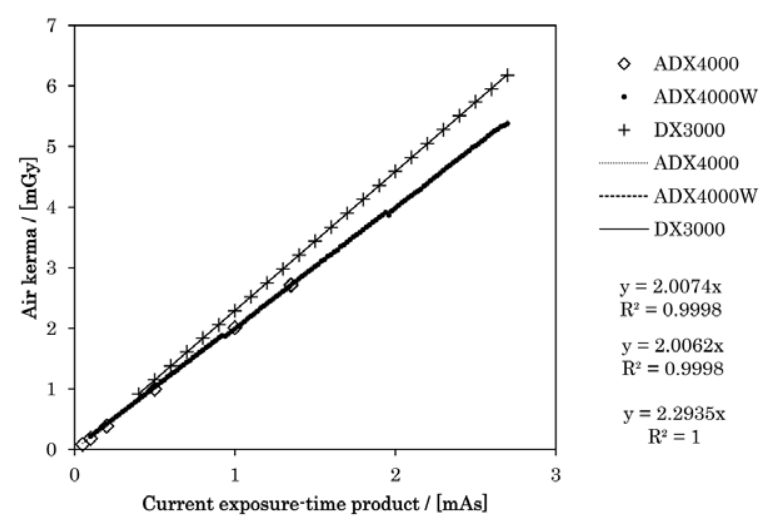

Fig. 7 Output air kerma in free air at the cone-tip ("cone tip dose") as a function of a current exposuretime product $(\mathrm{mAs})$ for portable intraoral X-ray units (ADX4000, ADX4000W, and DX3000) 


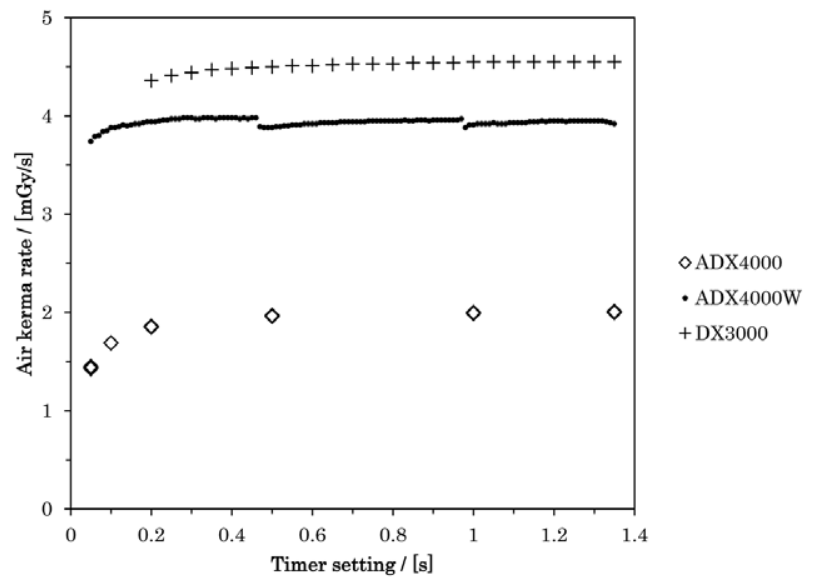

Fig. 8 Output air kerma rate in free air at the cone-tip as a function of timer settings for portable intraoral X-ray units (ADX4000, ADX4000W, and DX3000*) *The tube currents of the ADX4000W and DX3000 were $2 \mathrm{~mA}$, while the tube current of the ADX4000 was $1 \mathrm{~mA}$.

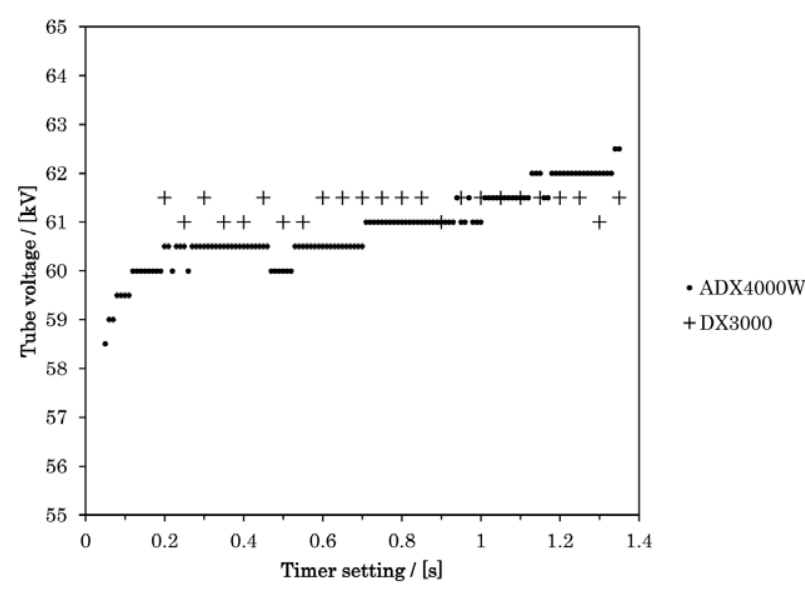

Fig. 9 Tube voltages as a function of timer settings for portable intraoral X-ray units ADX4000W and DX3000.

voltage of $60 \pm 2 \mathrm{kV}$. In the event that the timer was set at less than $0.2 \mathrm{~s}$, the tube voltage showed a systematic downward trend with the decrease in timer setting (Fig. 9). Accordingly, the half-value layer also showed a downward trend when the timer settings were short. As a whole, however, all of the units showed the halfvalue layer of $1.9 \pm 0.1 \mathrm{~mm} \mathrm{Al}$ as long as timer settings below 0.2 s were excluded (Fig. 10).

\section{X-ray Field and Field Size}

The ADX4000 showed a flat and uniform dose distribution in the direction perpendicular to the tube axis; in the direction parallel to the tube axis, a gradient indicating a decrease in dose was seen around the lower part of the unit. The measurement results of the ADX4000W

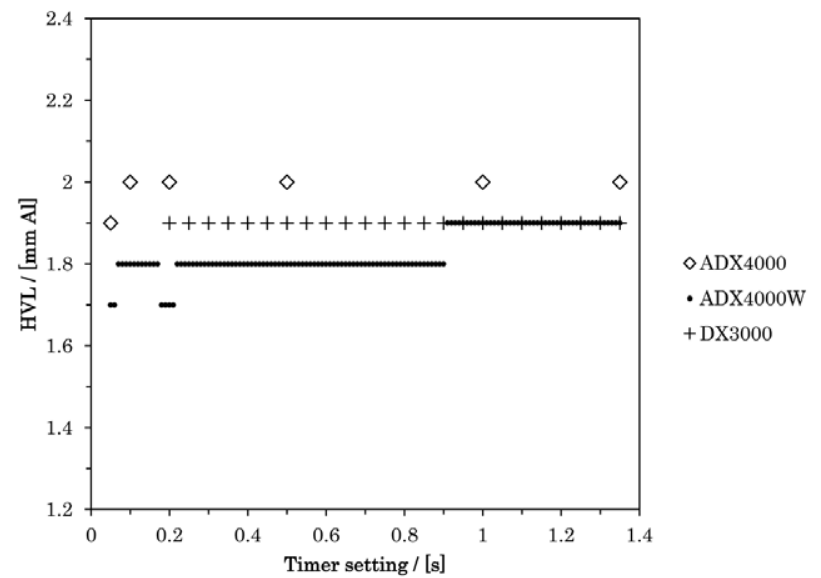

Fig. 10 Half-value layers as a function of timer settings for portable intraoral X-ray units (ADX4000, ADX4000W, and DX3000).

and DX3000 showed few differences between the dose distribution in the direction perpendicular to the tube axis and that of the direction parallel to the tube axis, and the gradient in the direction parallel to the tube axis was limited. The diameters of the X-ray fields obtained in the two directions were averaged and the following results were calculated: ADX4000 (60.9mm), ADX4000W $(60.3 \mathrm{~mm})$ and DX3000 (59.9mm) (Fig. 11a, b, c).

\section{Evaluation of Images}

The experienced dental radiologists (certified by the JSOMR) visually evaluated the images of the mandibular molar phantom obtained using the ADX4000, ADX4000W and DX3000 units (Fig. 12, 13, 14). In their judgment for exposure factors commensurate with diagnostic purpose, the optimum cone tip dose range for imaging with InSight film was 1.0-2.0mGy, while that for imaging with a CCD/CMOS digital X-ray sensor was one-third of the former, or 1/3-2/3mGy (about 0.33-0.67mGy).

\section{Stray Radiation}

For the stray radiation generated by the head phantom and the X-ray units of the ADX4000, ADX4000W and DX3000, the radii were set at $0.5 \mathrm{~m}$ and $1.0 \mathrm{~m}$ and the variations in air kerma in the horizontal direction and vertical direction depending on the angles were displayed in Fig. 15, 17 and 19 and Fig. 16, 18 and 20, respectively. The three units showed the following results in the horizontal and vertical directions shown in Fig. 5. The air kerma reached the maximum in the range of $0 \pm 15$ degrees of the forward direction of useful beams, while the air kerma reached the minimum in the range of 180 \pm 15 degrees backward. In the horizontal and vertical 

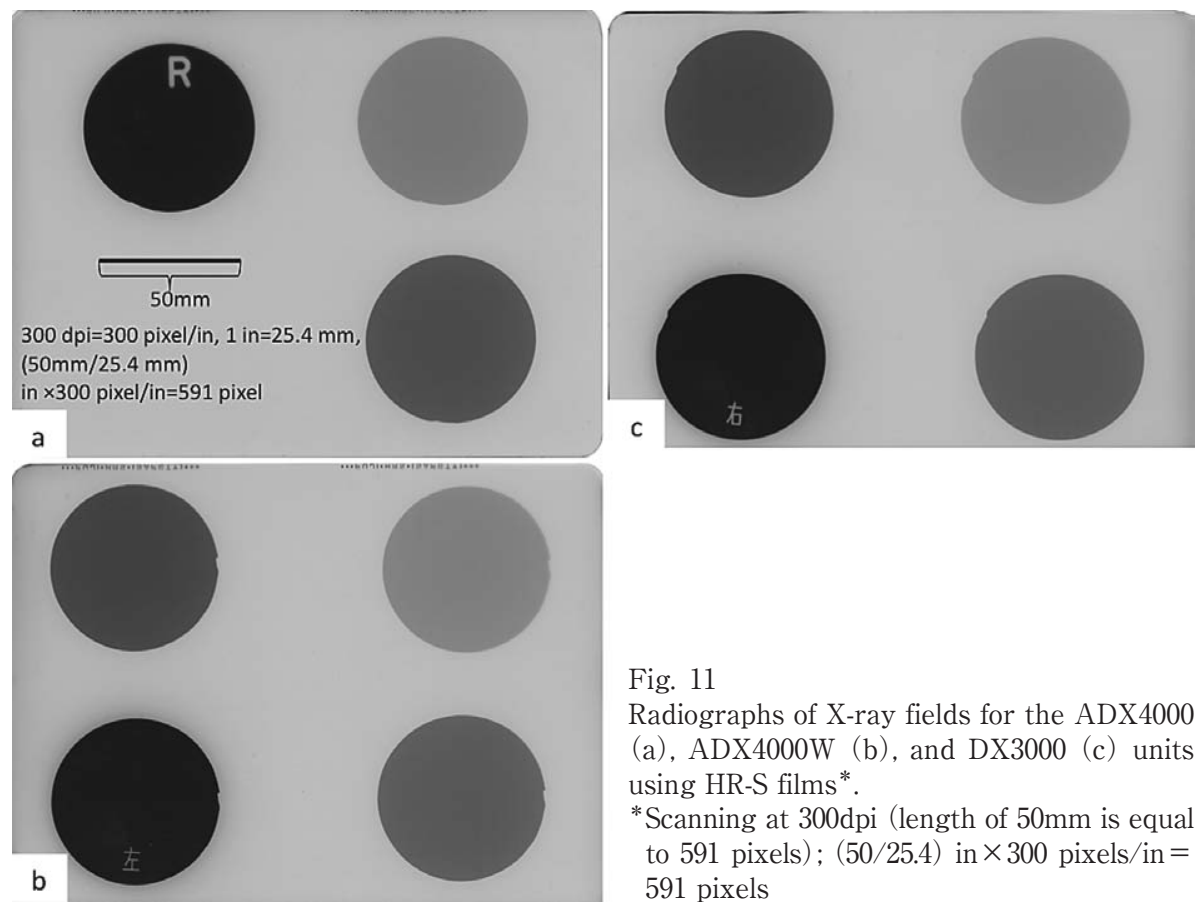

Fig. 11

Radiographs of X-ray fields for the ADX4000 (a), ADX4000W (b), and DX3000 (c) units using HR-S films*.

*Scanning at 300dpi (length of $50 \mathrm{~mm}$ is equal to 591 pixels); $(50 / 25.4)$ in $\times 300$ pixels $/$ in $=$ 591 pixels

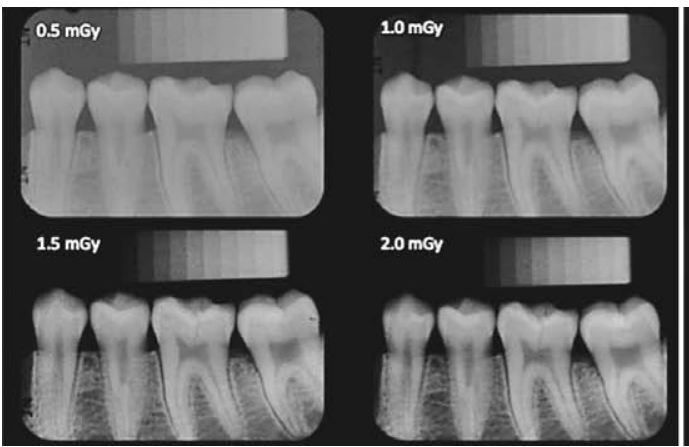

Film image

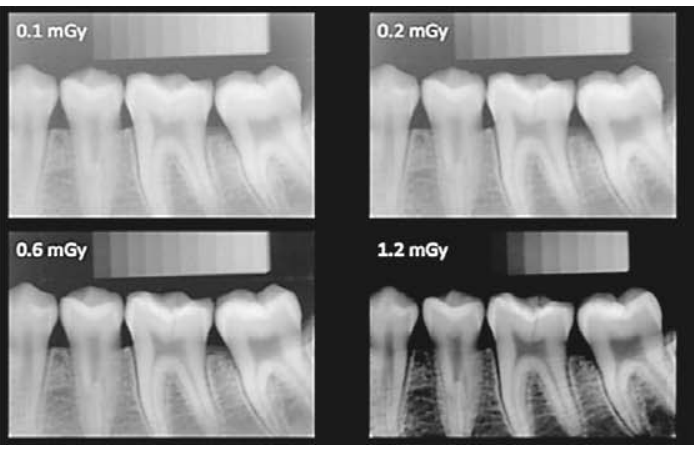

CCD image

Fig. 12 Intraoral radiographic images using InSight film for the ADX4000 unit compared to image sensors using a CCD.

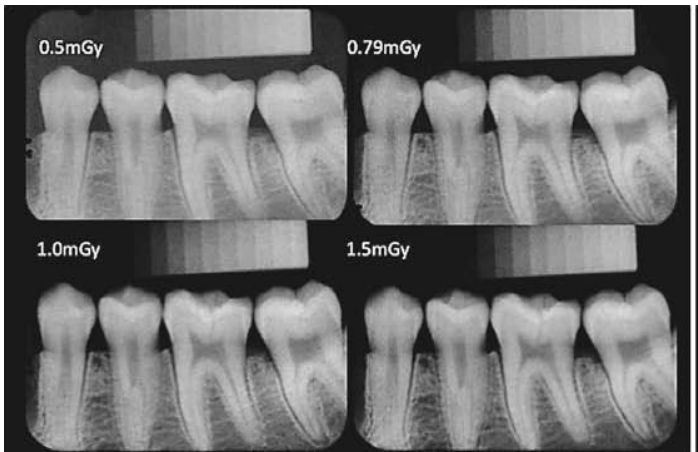

Film image

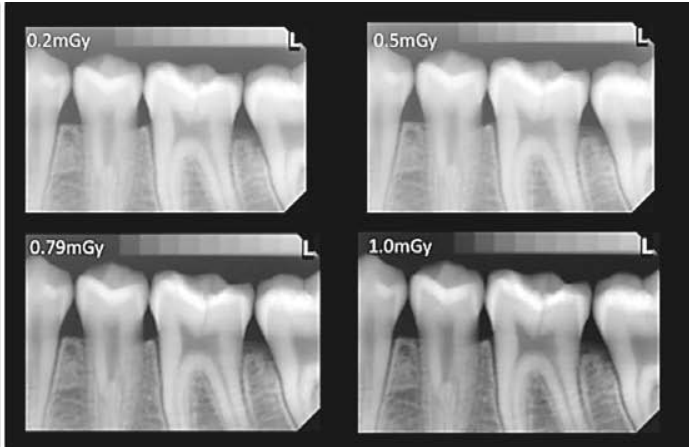

CMOS image

Fig. 13 Intraoral radiographic images using InSight film for the ADX4000W unit compared to image sensors using a CMOS. 


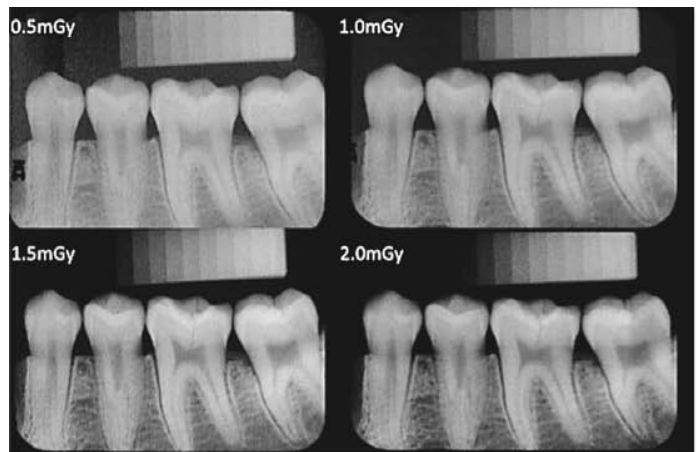

Film image

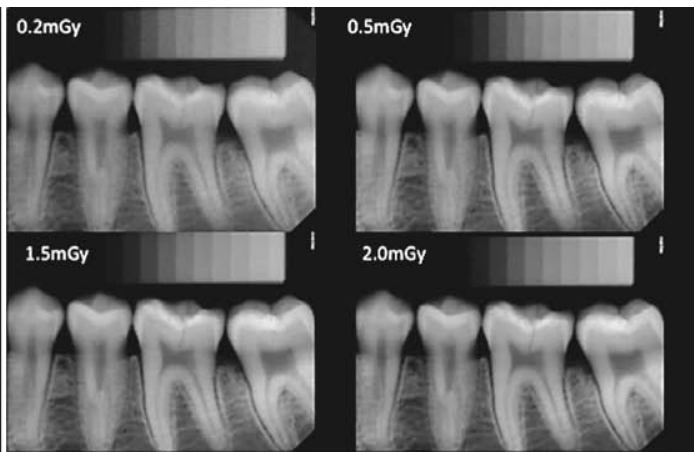

CMOS image

Fig. 14 Intraoral radiographic images using InSight film for the DX3000 unit compared to image sensors using a RVG6100 (CMOS).

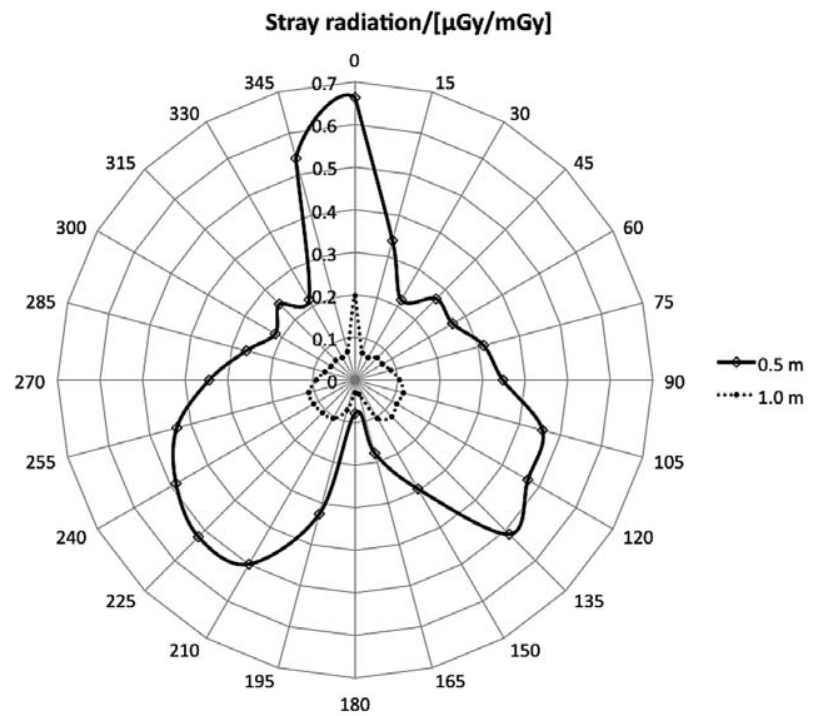

Fig. 15 Air kerma of stray radiation $[\mu \mathrm{Gy}]$ at the radii of $0.5 \mathrm{~m}$ and $1.0 \mathrm{~m}$ on the horizontal plane around a head phantom exposed to $1 \mathrm{mGy}$ at the cone tip of the ADX4000 unit.

directions, a comparison was made between the air kerma measured at a distance of $0.5 \mathrm{~m}$ and that measured at a distance of $1.0 \mathrm{~m}$. For the three units, the measurement results obtained in various directions were averaged. The average air kerma measured at a distance of $1.0 \mathrm{~m}$ was about one-fourth of that measured at a distance of $0.5 \mathrm{~m}$. The air kerma measured at a point sufficiently apart from the phantom decreased as the inverse square of distance. In the direction at an angle of zero degrees, we examined the decrease in air kerma to a distance of $2.0 \mathrm{~m}$ to confirm this finding. For each of the three units, the two dose assessment positions were selected, i.e., a position at an angle of zero degrees and a position in the

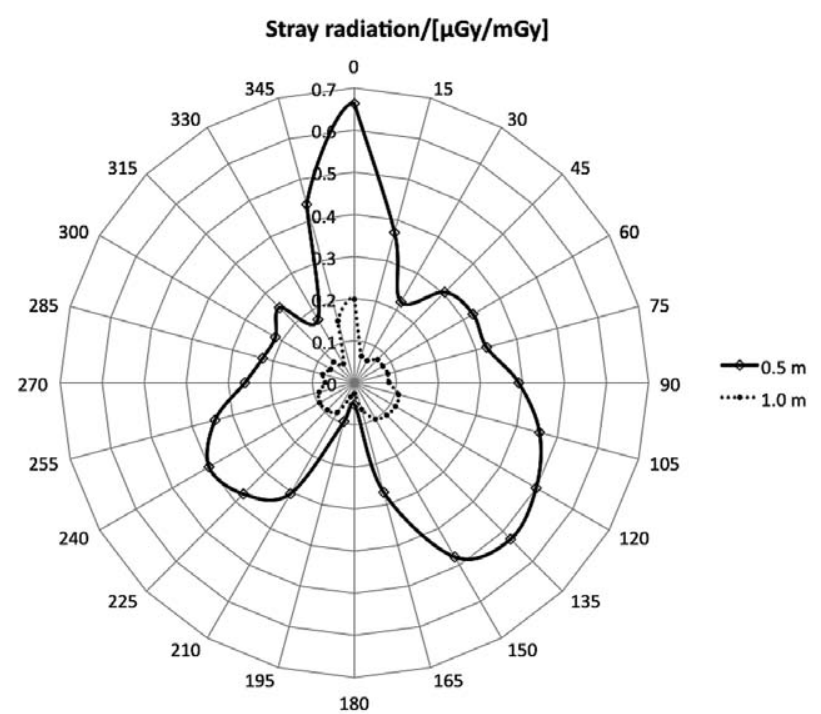

Fig. 16 Air kerma of stray radiation $[\mu \mathrm{Gy}]$ at the radii of $0.5 \mathrm{~m}$ and $1.0 \mathrm{~m}$ on the vertical plane around a head phantom exposed to $1 \mathrm{mGy}$ at the cone tip of the ADX4000 unit.

operator's work area, a sectioned area having an angle of $180 \pm 60$ degrees backward (the section ranging from 120-240 degrees), and the means of air kermas measured at these positions at distances of $0.5 \mathrm{~m}$ and $1.0 \mathrm{~m}$, are listed in Table 3.

Intraoral radiography are most frequently used to examine adult mandibular molars. Therefore, the cone tip dose using InSight film to examine an adult mandibular molar was determined at $2.0 \mathrm{mGy}$ to be safe for a conservative estimate of stray radiation exposure, according to the results in Section 3, Evaluation of Images. On the basis of the normalized values $(\mu \mathrm{Gy} / \mathrm{mGy})$ listed in Table 3, air kerma values $(\mu \mathrm{Gy})$ converted in terms of 


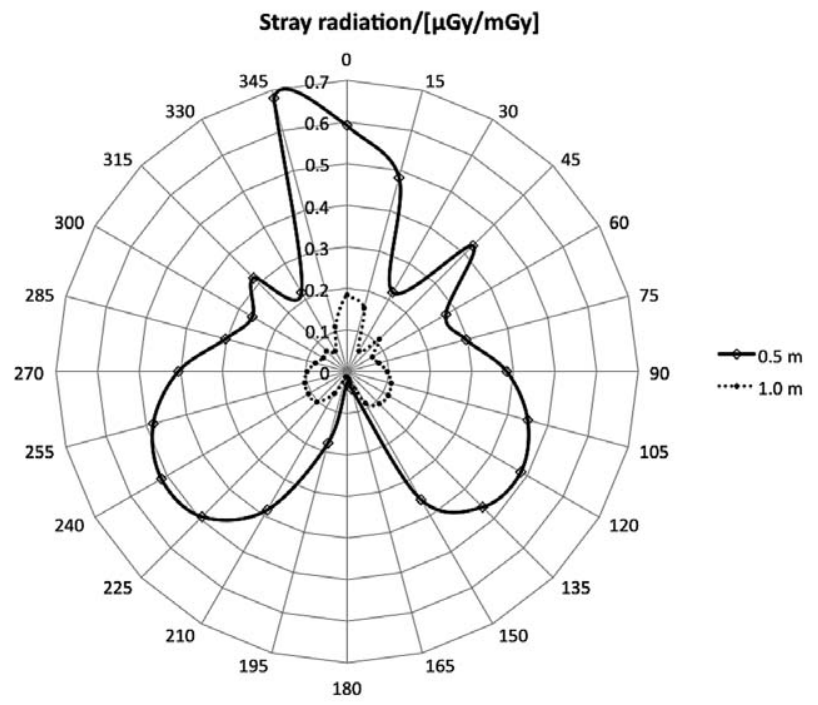

Fig. 17 Air kerma of stray radiation $[\mu \mathrm{Gy}]$ at the radii of $0.5 \mathrm{~m}$ and $1.0 \mathrm{~m}$ on the horizontal plane around a head phantom exposed to $1 \mathrm{mGy}$ at the cone tip of the ADX4000W unit.

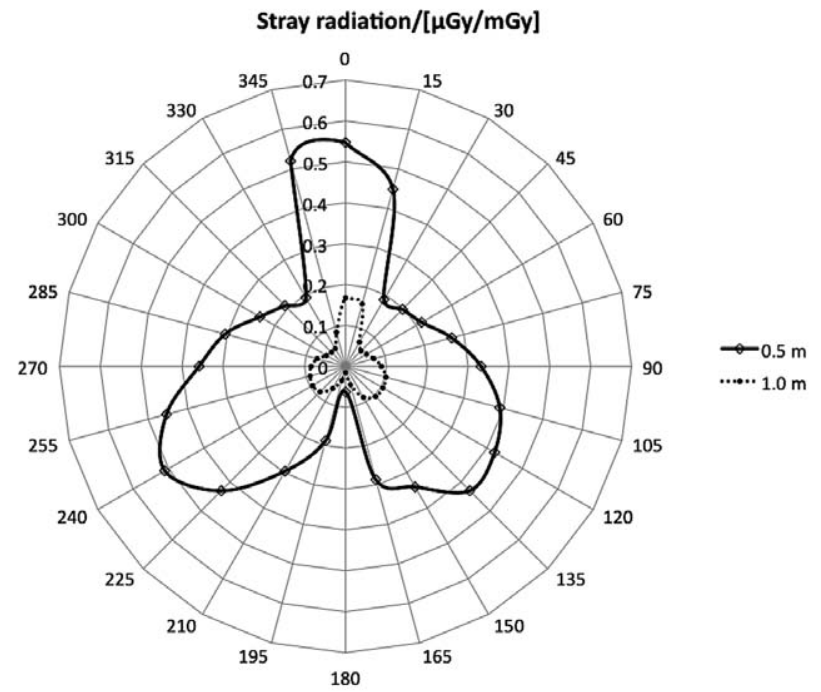

Fig. 19 Air kerma of stray radiation $[\mu \mathrm{Gy}]$ at the radii of $0.5 \mathrm{~m}$ and $1.0 \mathrm{~m}$ on the horizontal plane around a head phantom exposed to $1 \mathrm{mGy}$ at the cone tip of the DX3000 unit.

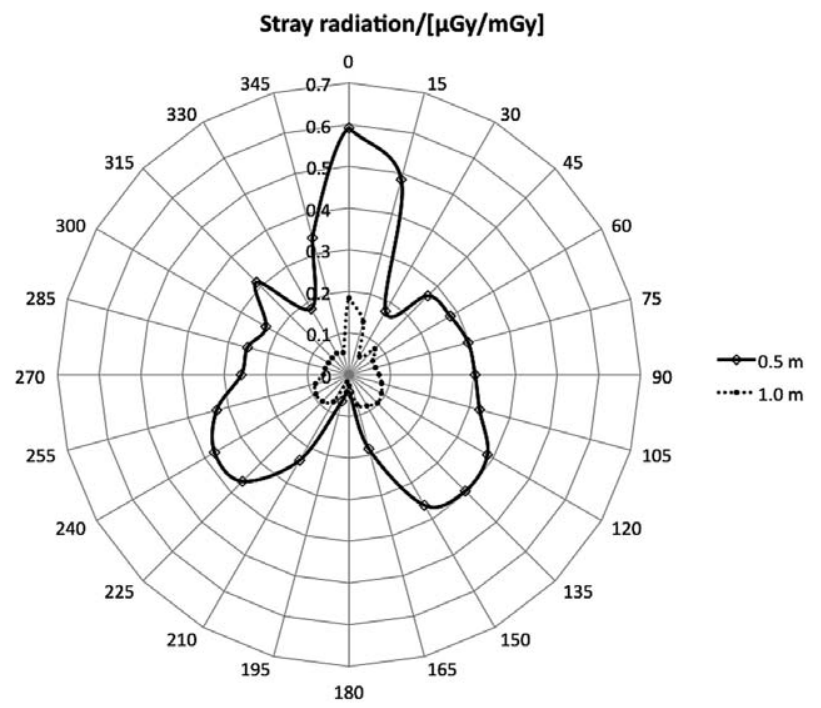

Fig. 18 Air kerma of stray radiation $[\mu \mathrm{Gy}]$ at the radii of $0.5 \mathrm{~m}$ and $1.0 \mathrm{~m}$ on the vertical plane around a head phantom exposed to $1 \mathrm{mGy}$ at the cone tip of the ADX4000W unit.

imaging with a single InSight film $(2.0 \mathrm{mGy})$ are also listed in Table 3. These values should be compared with the dose limits specified by the Ordinance for Enforcement of the Medical Care Act. For this purpose, the numerical values of air kerma were converted in terms of the unit of $\mathrm{Sv}$ by using the $1 \mathrm{~cm}$ dose equivalent conversion coefficient $(1.10 \mathrm{~Sv} / \mathrm{Gy})$ of external exposure ${ }^{15,16)}$

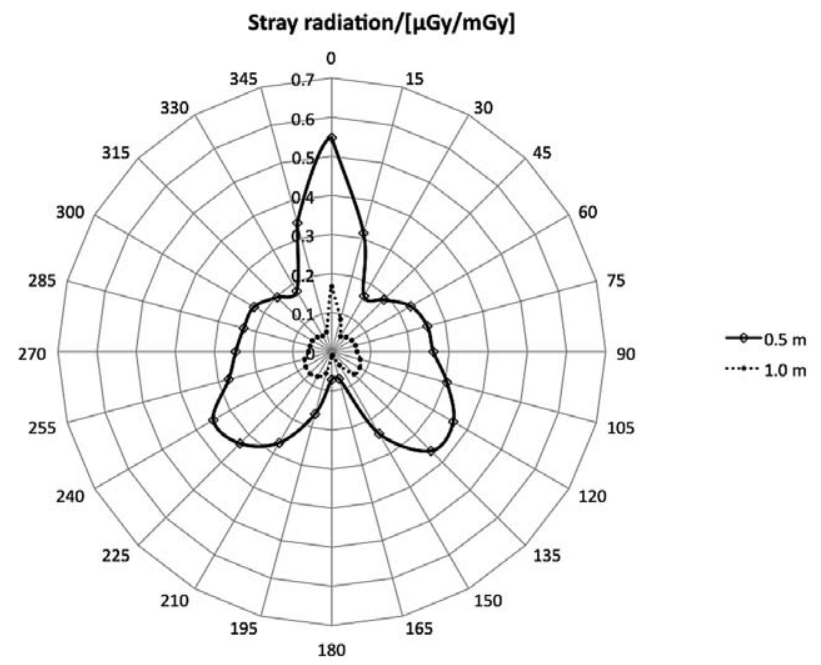

Fig. 20 Air kerma of stray radiation $[\mu \mathrm{Gy}]$ at the radii of $0.5 \mathrm{~m}$ and $1.0 \mathrm{~m}$ on the vertical plane around a head phantom exposed to $1 \mathrm{mGy}$ at the cone tip of the DX3000 unit.

at $30 \mathrm{keV}$ of photon energy (aluminum half-value layer $=$ In $2 / 3.05 \mathrm{~cm}^{-1}=2.28 \mathrm{~mm}$ ). In this manner, the evaluation values of ambient dose equivalent at $10 \mathrm{~mm}$ depth, $\mathrm{H}^{*}(10)$ were obtained. They are also listed in Table 3. When an attached CCD/CMOS or RVG6100 digital X-ray sensor was used, the evaluation value of $\mathrm{H}^{*}(10)$ for each imaging $(2 / 3 \mathrm{mGy})$ was reduced to one-third. 
Table 3 Normalized Air Kerma per $1 \mathrm{mGy}$ at the Cone Tip, Stray Radiation and Ambient Dose Equivalent of $\mathrm{H}^{*}(10)$ from the Head Phantom Exposed to $2 \mathrm{mGy}$ of X-ray at the Cone Tip

\begin{tabular}{|c|c|c|c|}
\hline \multirow[t]{2}{*}{ Model } & \multirow{2}{*}{$\begin{array}{l}\text { Angle for } \\
\text { Dosimetry }\end{array}$} & \multicolumn{2}{|c|}{$\begin{array}{l}\text { Normalized Air Kerma }[\mu \mathrm{Gy} / \mathrm{mGy}] / \\
\text { Stray Radiation }[\mu \mathrm{Gy}] / \mathrm{H}^{*}(10)[\mu \mathrm{Sv}] \dagger\end{array}$} \\
\hline & & $@ 0.5 \mathrm{~m}$ & $@ 1.0 \mathrm{~m}$ \\
\hline \multirow[b]{2}{*}{ ADX 4000} & $0^{\circ}$ & $0.663 / 1.326 / 1.459$ & 0.198/0.396/0.436 \\
\hline & $\begin{array}{l}120^{\circ} \sim 240^{\circ} \\
\left(180 \pm 60^{\circ}\right)\end{array}$ & $0.353 / 0.706 / 0.777$ & $0.084 / 0.168 / 0.185$ \\
\hline \multirow[b]{2}{*}{ ADX4000W } & $0^{\circ}$ & $0.592 / 1.184 / 1.302$ & $0.184 / 0.368 / 0.405$ \\
\hline & $\begin{array}{l}120^{\circ} \sim 240^{\circ} \\
\left(180 \pm 60^{\circ}\right)\end{array}$ & $0.297 / 0.594 / 0.653$ & $0.071 / 0.142 / 0.156$ \\
\hline \multirow[b]{2}{*}{ DX3000 } & $0^{\circ}$ & $0.547 / 1.094 / 1.203$ & $0.167 / 0.334 / 0.367$ \\
\hline & $\begin{array}{l}120^{\circ} \sim 240^{\circ} \\
\left(180 \pm 60^{\circ}\right)\end{array}$ & $0.288 / 0.576 / 0.634$ & $0.064 / 0.128 / 0.141$ \\
\hline
\end{tabular}

$\dagger$ The conversion coefficient used from air kerma to ambient dose equivalent of $\mathrm{H}^{*}(10)$ is $1.10 \mathrm{~Sv} / \mathrm{Gy}$ at $30 \mathrm{keV}$.

\section{Discussion}

\section{Output X-ray Characteristics}

The ADX4000 unit is a discontinued model. In the event of a large-scale disaster, it is expected that a wide variety of units, including new and former models, would be used for intraoral radiography. Therefore, the basic performance of former models should also be analyzed and evaluated. In this study, we examined three units for timer accuracy (Fig. 6), cone tip dose mAs linearity (Fig. 7), stability of the cone tip dose rate (Fig. 8) and $\mathrm{X}$-ray beam quality according to the tube voltage and half-value layer (Fig. 9, 10). From a comprehensive viewpoint, these units were slightly unstable in output dose rate and X-ray beam quality for $0.05-0.5 \mathrm{~s}$, while they were stable for $0.5-1.35 \mathrm{~s}$. For intraoral radiography using InSight film (E/F speed group) on an adult patient, a cone tip does of about $1-2 \mathrm{mGy}$ is frequently used, and there are no great differences more than other research results (The results of this study, which cover DXPS's results of X-ray set assessments over the calendar years 2002 to 2004, demonstrate that the third quartile dose for intra oral radiography has now fallen to $2.4 \mathrm{mGy}.)^{17,18)}$. These units perform sufficiently when used for this purpose. However, we may need to obtain images at much lower doses using digital X-ray sensor technology with higher sensitivity or may be examining pediatric patients. In these instances, we need to use
$0.05 \mathrm{~s}-0.5 \mathrm{~s}$ of exposure time. For these situations, further improvement in performance for short-time output is needed.

\section{X-ray Field}

In the experiment using the ADX4000 unit, the dose uniformity in the X-ray field was examined and the following results were obtained. Relatively satisfactory symmetry was observed in the direction perpendicular to the X-ray tube axis on the right and left sides of the unit. The dose markedly decreased in the direction parallel to the tube axis from the upper part to the lower part of the unit. This marked decrease in dose was probably due to the heel effect resulting from the position of anode in the lower part of the unit (Fig. 11a). Unlike the ADX4000, the ADX4000W and DX3000 units have tube axes on their right and left sides, and the anodes are located on the left arms that support the units. Although there was a slight dose gradient between the right and left sides, there was no marked difference from the vertical direction (Fig. 11b, c). X-ray tubes of the same type were used for these units (Table 2) but the inter-unit difference is probably due to the difference in device design.

According to the Ordinance for Enforcement of the Medical Practitioners' Act (Article 30-3), the field size of an intraoral X-ray unit should not exceed $6 \mathrm{~cm}$ of a diameter ${ }^{15}$. In this study, the diameters of the X-ray fields of the ADX4000 and ADX4000W slightly exceeded $6 \mathrm{~cm}$, 
while the diameter of the radiation field of the DX3000 was less than $6 \mathrm{~cm}$. The external margins of the radiation fields measured in this study were consistently irregular (Fig. 11). The X-ray field was limited by lining the internal cone wall with a lead sheet. In principle, the $\mathrm{X}$-ray field should be designed so that the diameter does not exceed $6 \mathrm{~cm}$ by using the collimator of the X-ray tube window. Shielding the internal cone wall would likely be effective in protecting patients from scattered radiation.

3. Evaluation of Images

We compared the three units with respect to their InSight film images and $\mathrm{CCD} / \mathrm{CMOS}$ digital images (Fig. $12,13,14)$. According to the results, CCD/CMOS digital imaging ensured sufficient image quality for intraoral X-ray diagnostic imaging by using about one-third of the dose that is required for InSight film imaging. Therefore, as demonstrated by many reported cases ${ }^{19)}$, exposure could be reduced remarkably by using a unit with a digital X-ray sensor.

4. Stray Radiation

1) Air Kerma of Stray Radiation

Sato and Furumoto ${ }^{7)}$ simulated intraoral X-ray beams under the following conditions: tube voltage $(60 \mathrm{kV})$, total filtration $(2.0 \mathrm{~mm} \mathrm{Al}$ eq.), half-value layer $(1.95 \mathrm{~mm}$ $\mathrm{Al})$ and effective energy $(28.2 \mathrm{keV})$. X-ray irradiated a spherical water phantom $18 \mathrm{~cm}$ in diameter, and the field having a focus-surface distance of $20 \mathrm{~cm}$ and a diameter of $5 \mathrm{~cm}$. Air kerma at a distance of $1.0 \mathrm{~m}$ from the center of phantom was then calculated using the Monte Carlo method. According to the calculation results, air kerma rapidly decreased ahead of the beams at scattered angles ranging from zero degrees to 30 degrees. With a further increase in angle, air kerma gradually increased behind the beams to an angle of 180 degrees. In the present study, we used beams with a similar X-ray quality and a $16 \mathrm{~cm}$ diameter $\times 15 \mathrm{~cm}$ height PMMA cylindrical phantom for measurement. We measured the air kerma generated by the phantom and the three units under the following conditions: radii of $0.5 \mathrm{~m}$ and $1.0 \mathrm{~m}$, and both horizontal and vertical directions. Our results of measurement at angles ranging from zero degrees to 120 degrees and angles ranging from 240 degrees to 360 degrees showed a tendency that was similar to the calculation results reported by Sato and Furumoto. Outside these angle ranges, the measurement results indicated a decrease in air kerma and achieved the minimum value at angles of about 180 degrees. These measurement results were different from the calculation results. The air kerma measured in the zero-degree direction reflected the Xrays regarded mainly as the useful beams attenuated and scattered by the phantom, while air kerma measured in directions other than the zero-degree direction included the scattered radiation from the phantom, leakage radiation from the X-ray unit and other stray radiation. In the latter case, air kerma generally reflected the scattered radiation generated from the phantom.

As specified by the Ordinance, with the exception of useful beams, intraoral X-ray units should have shielding so that the air kerma rate at a distance of $1 \mathrm{~m}$ from the focus will be below $0.25 \mathrm{mGy} / \mathrm{h}$ (Article 30-1) ${ }^{15}$. The shields around the X-ray tube and inside the treatment cone and the shielding on the X-ray unit itself are likely to remarkably attenuate the backward scattered radiation generated by the phantom ${ }^{4,5)}$. The calculated scatter radiation did not include these shielding effects ${ }^{7}$. The difference from the calculated value seemed to be due to this phenomenon. In the event that the dose distribution of useful beams in the circular radiation field is uniform, the dose distribution symmetrical around the central X-ray axis is displayed in the calculation of Compton scattering due to the spherical water phan$\mathrm{tom}^{7}$. In terms of the distribution of air kerma measured at angles from zero degrees to 120 degrees and from 240 degrees to 360 degrees, gaps were noticed between the horizontal direction and the vertical direction. These gaps seemed to be affected by the difference between the shape of the cylindrical phantom in the horizontal direction and that in the vertical direction. Moreover, in terms of the distribution of air kerma at angles other than the above, gaps were also noticed between the horizontal direction and the vertical direction. These gaps seemed to be produced additionally by differences in the shielding structure between the units. In the experiment using the ADX4000, in terms of symmetry with respect to the central X-ray, the distribution of air kerma in the vertical direction was worse than that in the horizontal direction. Because the axis of the X-ray tube was placed in the vertical direction of the unit, the heel effect produced the dose gradient in the X-ray field. Unlike the ADX4000, neither the ADX4000W nor the DX3000 showed a marked difference in stray radiation in the two directions. This finding reflected the similarity of dose distribution in the X-ray fields in the two 
directions.

2) Influence of Distance on Stray Radiation

Because of the detection limit of the measurement device, air kerma at positions $2.0 \mathrm{~m}$ apart from the phantom, except in a forward direction at an angle of zero degrees, could not be measured. In addition to the comparison between air kerma in various directions at distances of $0.5 \mathrm{~m}$ and $1.0 \mathrm{~m}$, air kerma at a position $2.0 \mathrm{~m}$ apart from the phantom could be estimated from the inverse square $(1 / 16)$ of air kerma at a distance of $0.5 \mathrm{~m}$. The assurance of sufficient distance from the radiation source is important to promote protection for controlling exposure to radiation generated by the phantom and the portable intraoral X-ray units.

3) The Safe Use of Portable Intraoral X-ray Units

According to the Ordinance for Enforcement of the Medical Practitioners' Act ${ }^{15)}$, a radiation worker should not be exposed occupationally to radiation at an effective dose exceeding $100 \mathrm{mSv}$ for five years $(20 \mathrm{mSv} /$ year). (The annual occupational exposure to radiation should not exceed $50 \mathrm{mSv}$.) In the event that caregivers and other workers are included in the public, members of the public should not be exposed to radiation at a dose exceeding $1 \mathrm{mSv} /$ year $\left(250 \mu \mathrm{Sv} / 3\right.$ months) (Article 30-27) ${ }^{15}$ ). Places where people may be at a risk of being exposed to radiation at a dose exceeding $1.3 \mathrm{mSv} / 3$ months must be designated as a control area (Article 30-16) and strictly monitored ${ }^{15)}$. On the assumption that one year has 52 months, three months have 13 weeks and people work five days a week, they work for 260 days per year or for 65 days every three months. Occupational exposure should not exceed $76.9 \mu \mathrm{Sv} /$ day $(20 \mathrm{mSv} / 260$ days $)$ and public exposure should not exceed $3.85 \mu \mathrm{Sv} /$ day ( $1 \mathrm{mSv} / 260$ days). The places where people may be at a risk of being exposed to radiation at a dose exceeding $20 \mu \mathrm{Sv} /$ day $(1.3 \times 4 \mathrm{mSv} / 260$ days $)$ must be designated as a control area and the operators working there should be protected sufficiently from being exposed to radiation.

Occupational exposure to radiation resulting from taking only a few radiographs per day for identification or from taking a radiograph during a home dental treatment is limited. In the event of a disaster, however, operators would be taking many radiographs per day. Therefore, occupational exposure and public exposure should be controlled properly. The control area should also be designated appropriately. These procedures should be followed to ensure the safety of the staff en- gaged in victim identification operations. Portable intraoral X-ray units cannot be used in the special X-ray room at the time of a disaster. In this situation, appropriate actions should be taken to prevent operators, caregivers and other workers around the units from being exposed to radiation. In the present study, the significant zone of occupancy for an operator was defined as a sectioned area with an angle of $180 \pm 60$ degrees in both vertical and horizontal directions, recommended from the viewpoint of safe use of an X-ray unit. Protection of an operator from exposure to radiation was considered by calculating the mean of ambient dose equivalent at $10 \mathrm{~mm}$ depth, $\mathrm{H}^{*}(10)$ in both directions in the sectioned area. To protect the caregivers and other workers from being exposed to radiation, the worst-case scenario was considered and the mean $\mathrm{H}^{*}(10)$ in both directions at an angle of zero degrees corresponding to the maximum exposure was used for evaluation.

According to the evaluation value of $\mathrm{H}^{*}(10)$ per imaging with InSight film as shown in Table 3, operators of X-ray units should be protected from radiation exposure during work and the public, including caregivers, should also be protected from exposure to radiation. For this purpose, X-ray units should be used in the following safe manner. Operators should use the units to take radiographs at a distance of $0.5 \mathrm{~m}$ in the sectioned area that has an angle of $180 \pm 60$ degrees. Under this condition, the following numerical values were obtained. The daily dose limit for a radiation worker was divided by mean $\mathrm{H}^{*}(10)$ at the evaluation position per imaging to calculate the number of images to be taken until the achievement of the dose limit (Table 4). According to the estimation shown in Table 4, the annual effective dose limit for radiation workers $(20 \mathrm{mSv} /$ year or $76.9 \mu \mathrm{Sv} /$ day $)$ may be reached if an operator takes about 100 radiographs per day with any of these units (300 radiographs when an attached digital X-ray sensor is used). In this situation, the cumulative cone tip dose is $0.2 \mathrm{~Gy}(2 \mathrm{mGy} \times 100)$ and these three units are to be used in the condition of about $100 \mathrm{mAs}$ (Fig. 7 ). In event that an operator needs to take more than 100 radiographs, he/she should take effective countermeasures against radiation. For example, they should utilize either a lead apron $(0.25 \mathrm{~mm} \mathrm{~Pb}$ eq.; lead apron that can control $99 \%$ of scattered radiation resulting from a $60 \mathrm{kV}$ X-ray) or a protection board, or else remote control system for radiography. The dose seems to decrease as the inverse square of the distance. 
Table 4 Number of Radiographs Per Day Exposed to Effective Dose Limits of $76.9,20.0$, and $3.85 \mu \mathrm{Sv}$ at the Radii of $0.5,1.0$, and $2.0 \mathrm{~m}$ from the Center of the Head Phantom

\begin{tabular}{|c|c|c|c|c|}
\hline \multirow{2}{*}{ Model } & \multirow{2}{*}{$\begin{array}{l}\text { Angle for } \\
\text { Dosimetry }\end{array}$} & \multicolumn{3}{|c|}{$\begin{array}{l}\text { Number of Radiographs per Day } \\
\text { (InSight Film }) \dagger\end{array}$} \\
\hline & & $\begin{array}{c}76.9 \mu \mathrm{Sv}^{\mathrm{a})} \\
@ 0.5 \mathrm{~m}\end{array}$ & $\begin{array}{c}20.0 \mu \mathrm{Sv}^{\mathrm{b})} \\
\text { (@) } 1.0 \mathrm{~m}\end{array}$ & $\begin{array}{l}3.85 \mu \mathrm{Sv}^{\mathrm{c})} \\
@ 2.0 \mathrm{~m}\end{array}$ \\
\hline \multirow[b]{2}{*}{ ADX 4000} & $0^{\circ}$ & - & 46 & 42 \\
\hline & $\begin{array}{l}120^{\circ} \sim 240^{\circ} \\
\left(180 \pm 60^{\circ}\right)\end{array}$ & 99 & 108 & 79 \\
\hline \multirow[b]{2}{*}{ ADX 4000W } & $0^{\circ}$ & - & 49 & 47 \\
\hline & $\begin{array}{l}120^{\circ} \sim 240^{\circ} \\
\left(180 \pm 60^{\circ}\right)\end{array}$ & 118 & 128 & 94 \\
\hline \multirow[b]{2}{*}{ DX3000 } & $0^{\circ}$ & - & 54 & 51 \\
\hline & $\begin{array}{l}120^{\circ} \sim 240^{\circ} \\
\left(180 \pm 60^{\circ}\right)\end{array}$ & 121 & 142 & 97 \\
\hline
\end{tabular}

$\dagger$ Number of radiographs (InSight film) reaching the values of ambient dose equivalent of $\mathrm{H}^{*}(10)$ per day to be a) $76.9 \mu \mathrm{Sv}$, b) $20.0 \mu \mathrm{Sv}$, and c) $3.85 \mu \mathrm{Sv}$ at the radii of $0.5,1.0,2.0 \mathrm{~m}$ (When an attached CCD/CMOS or RVG6100 digital X-ray sensor is used, number of radiographs that can be taken using the digital sensor is three-fold that can be taken using InSight film, as the dose associated with the digital sensor is one-third that for InSight film.)

a) Limit of effective dose for occupational exposure is $20 \mathrm{mSv}$ per year equal to $76.9 \mu \mathrm{Sv} / \mathrm{d}$

b) The control area must be set above the effective dose of $1.3 \mathrm{mSv}$ per 3 months equal to $20.0 \mu \mathrm{Sv} / \mathrm{d}$

c) Limit of effective dose for public exposure is $1 \mathrm{mSv}$ per year equal to $3.85 \mu \mathrm{Sv} / \mathrm{d}$

Therefore, the number of radiographs that an operator can take increases to $400(100 \times 4)$ at a distance of $1.0 \mathrm{~m}$ and $1,600(100 \times 16)$ at a distance of $2.0 \mathrm{~m}$. In the sectioned area that has an angle of $180 \pm 60$ degrees, the dose at a distance of $1.0 \mathrm{~m}$ may exceed $1.3 \mathrm{mSv} / 3$ months $(20 \mu \mathrm{Sv} /$ day $)$ (Table 4$)$. For this reason, the internal area should be designated as the control area. In areas other than the sectioned area with an angle of $180 \pm 60$ degrees, for example, the side areas and the front area at an angle of zero degrees, air kerma at a distance of $1.0 \mathrm{~m}$ reaches a level more than twice as high as the mean level of $\mathrm{H}^{*}(10)$ in the sectioned area backward at an angle of $180 \pm 60$ degrees (Fig. 15, 17, 19; Fig. 16, 18, 20; Table 4). Moreover, shields or barriers may not be used to reduce doses. In these cases, along the direction from the side to the front, the area reaching the border more than $1.5-2.0 \mathrm{~m}$ apart from the radiation source should be designated as the control area. In the absence of shields, the control area should be designated in consideration of these conditions in the manner displayed in Fig. 21. If we adopt the annual dose limit for the public $(1 \mathrm{mSv} /$ year; $3.85 \mu \mathrm{Sv} /$ day) under these conditions, as shown by the estimation in Table 4, sufficient considerations, such as ensuring a distance of more than $2.0 \mathrm{~m}$ from the radiation source, are indispensable for operators take radiographs in the temporary facilities without shielded radiography rooms that would be constructed after a disaster, or for those taking radiographs for home care. However, the number of radiographs does not increase considerably as long as an operator would be taking only a few radiographs for identification or when providing routine home care for dental treatment.

In the event of a large-scale disaster, an operator would be taking radiographs of many victims' entire jaw 


\section{An example of the control area setting $3(\mathrm{~L}) \times 3(\mathrm{H}) \times 3(\mathrm{~W}) \mathrm{m}^{3}$}

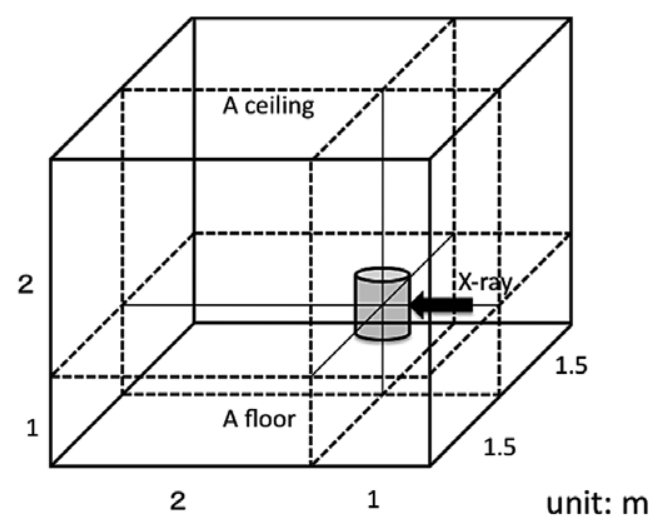

Fig. 21 An example of setting up a control area (unit: $\mathrm{m}$ )

X-ray beam indicated as the arrows of a symbol $(-)$ in Fig. 21.

bones. Therefore, the number of radiographs that an operator would be taking per day would increase tremendously. If an operator conducts intraoral full mouth radiographs on 10 bodies using any of the three units and takes 10 images with InSight film, he/she is exposed to radiation at the daily dose limit listed in Table 4 . In the event a unit with a digital X-ray sensor is used, the estimation increases threefold and reaches about 300 images. At the time of a large-scale disaster, as illustrated in Fig. 21, a work space of $3 \mathrm{~m}$ depth $\times 3 \mathrm{~m}$ width (floor) $\times 3 \mathrm{~m}$ height (from the floor to the ceiling) should be ensured. The floor below the work space may be used as the residential area for the public. In this case, sufficient caution should be exercised to ensure their safety. Portable intraoral units may be used according to the illustrated arrangement (Fig. 21). This work space should be designated as the control area and strict measures should be taken to prevent the public from entering without permission. Occasionally, ensuring such a work space for dental radiography may be difficult. In this case, shield walls or protection boards should be fixed so that the dose outside the shield does not exceed $1.3 \mathrm{mSv} / 3$ months. A worker should operate the portable X-ray unit from outside the control area. However, the worker may need to operate the unit inside the control area. Then, he/she is advised to wear a lead apron $(0.25 \mathrm{~mm} \mathrm{~Pb}$ eq. $)$ to reduce occupational exposure.

In addition to operators, other people may transiently enter the control area. If they are using InSight film to take about 100 radiographs per day and are engaged in dental radiography for five days a week, they may be exposed to radiation at a dose exceeding $100 \mu \mathrm{Sv}$ $(20 \mu \mathrm{Sv} / \mathrm{d} \times 5 \mathrm{~d}=100 \mu \mathrm{Sv})$. Accordingly, individual exposure should be monitored as specified by the Ordinance for Enforcement of the Medical Practitioners' Act ${ }^{15)}$.

\section{Conclusions}

Three portable intraoral X-ray units, the ADX4000, ADX4000W, and DX3000 were investigated in this study. Digital X-ray sensors were attached to the former two units. Their outputs were measured, the images evaluated and air kerma was determined. The findings are summarized below.

Output characteristics: According to the results of measurement of dose, tube voltage, dose rate, half-value layer and exposure time, the output characteristics of these three units were stabilized for more than $0.5 \mathrm{~s}$ and appropriately controlled within the range of doses routinely used. The X-ray fields of the ADX4000 and ADX4000W units slightly exceeded $60 \mathrm{~mm}$ in diameter, although the X-ray field of the DX3000 was below $60 \mathrm{~mm}$ in diameter.

Stray radiation: Regarding stray radiation during intraoral radiography, the distribution of air kerma differed depending on the structure of each unit. However, in any of the three units, air kerma was distributed in a nearly symmetric fashion with respect to the central Xray. The dose reached the maximum level in range at an angle of $0 \pm 15$ degrees ahead of the useful beams, while the dose reached the minimum level in range at an angle of $180 \pm 15$ degrees backward on the opposite side where an irradiated part of the phantom was hidden behind the unit. An operator may work in a sectioned area that has an angle of $180 \pm 60$ degrees at a distance of $0.5 \mathrm{~m}$. In this case, mean air kerma of stray radiation per cone tip dose of $1 \mathrm{mGy}$ of each unit was as follows: $0.353 \mu \mathrm{Gy}$ (ADX4000), 0.297 $\mu \mathrm{Gy}$ (ADX4000W) and $0.288 \mu \mathrm{Gy}$ (DX3000). To control occupational exposure in this study we used 1.10Sv/Gy, which was obtained by the conversion from the air kerma of $30 \mathrm{keV}$ photon energy to the ambient dose equivalent at $10 \mathrm{~mm}$ depth.

Safe use: In the event of a large-scale disaster, operators would be taking many radiographs for victim identification in facilities without X-ray rooms. If an operator uses InSight film and takes about 100 radiographs per 
day (300 radiographs if an attached digital X-ray sensor is used, at a cumulative cone tip dose $0.2 \mathrm{~Gy}$ ), the operator may be exposed to radiation at a level that exceeds the occupational dose limit $(20 \mathrm{mSv} /$ year $=76.9 \mu \mathrm{Sv} /$ day $)$. During a period of extensive victim identification work, a control area should be designated appropriately, the operator should control the unit from a vantage point of more than $2 \mathrm{~m}$ away from the radiation source, the operator should wear a lead apron $(0.25 \mathrm{~mm} \mathrm{~Pb}$ eq.) and a protection board should be fixed. However, these protective measures are not always necessary if intraoral radiography is needed on a transient basis.

\section{Acknowledgments and conflicts of interest}

This work was supported by JSPS KAKENHI Grant Number JP15K20648.

There is conflict of interest in this research. In this work, we researched X-ray units (DEXICO ADX4000, DEXICO ADX4000W, and DEXICO DX3000) lent from 10DR Japan.

\section{References}

1) Goren, A.D., Bonvento, M., Biernacki, J., et al.: Radiation exposure with the NOMAD ${ }^{\mathrm{TM}}$ portable X-ray system. Dentomaxillofacial Radiol, 37 : 109-112, 2008.

2) Danforth, R.A., Herschaft, E.E. and Leonowich, J.A.: Operator Exposure to Scatter Radiation from a Portable Handdheld Dental Radiation Emitting Device (Aribex ${ }^{\mathrm{TM}}$ NORMAD $^{\mathrm{TM}}$ ) While Making 915 Intraoral Dental Radiographs. J Forensic Sci, 54 : 415-421, 2009.

3) Pittayapat, P., Thevissen, P., Fieuws, S., et al.: Forensic oral imaging quality of hand-held dental X-ray devices: Comparison of two image receptors and two devices. Forensic Science International, $194: 20-27,2010$.

4) Gray, J., Bailey, E.D. and Ludlow, J.B.: Dental Staff Doses with Handheld Dental Intraoral X-ray Units. Health Physics, $102: 137-142,2012$.

5) Bailey, E., Gray, J. and Ludlow, J.: Image Quality and Radiation Dose for Intraoral Radiography: Hand-Held (Normad), Battery Powered vs. Wall-Mount X-Ray Systems. 41st Annual Conference on Radiation Control Conference of Radiation Control Program Directors. May 18-21, 2009. http://www.
aribex.com/wp-content/uploads/file/pdf/DosimetryStudy CRCPD.pdf Accessed December 29, 2016.

6) Kim, E.K.: Effect of the amount of battery charge on tube voltage in different hand-held dental $\mathrm{x}$-ray system. Imaging Science in Dentistry, $42: 1-4,2012$.

7) Sato, K. and Furumoto, K.: On Dose and Beam Quality of Scattered X-ray during Dental Intraoral Radiography - A Computer Simulation Study - Dental Radiology, 23 : 189203, 1983 (in Japanese).

8) Kuroyanagi, K., Hayakawa, Y., Fuimori, H., et al.: Distribution of scattered radiation during intraoral radiography with the patient in supine position. Oral Surg Oral Med Oral Pathol Oral Radiol Endod, 85 : 736-741, 1998.

9) de Haan, R.A. and van Aken, J.: Effective dose equivalent to the operator in intra-oral dental radiography. Dento-MaxilloFacial Radiology, 19 : 113-118, 1990.

10) Willianmson, G.F.: Intraoral Radiography: Positioning and Radiation Protection. A - Peer-Reviewed Publication. https://www.dentalacademyofce.com/courses/1455/pdf/ intraoralradiography.pdf Accessed December 29, 2016.

11) ADA: Recommendations for patient selection and limiting radiation exposure. http://www.fda.gov/downloads/ Radiation-EmittingProducts/RadiationEmittingProductsand Procedures/MedicalImaging/MedicalX-Rays/UCM329746. pdf Accessed December 29, 2016.

12) Office Of Radiation Safety, Ministry of Health: RADIATION PROTECTION for DENTISTS and ASSISTANTS. https:// www.health.govt.nz/system/files/documents/pages/43. dental_pamphlet.doc Accessed December 29, 2016.

13) Carestream Dental - Radiation Safety in Dental Radiography. http://www.carestreamdental.com/ImagesFileShare/. sitecore.media_library.Files.Film_and_Anesthetics.Proof 8179USRadiationSafetyBrochureRev4.pdf Accessed December 29, 2016.

14) Willis, S.J., Green, S. and Cobb, C.J.: A study to determine the spatial distribution of scattered radiation during dental intra-oral radiography. ECR 2014 Poster No. C-1795.

15) Ordinance for Enforcement of the Medical Practitioners' Act.

16) ICRU: Conversion Coefficients for Use in Radiological Protection against External Radiation. ICRU Report 57 (ICRU Publications: Bethesda), 1998.

17) Gulson, A.D., Knapp, T.A. and Ramsden, P.G.: Doses to Patients arising from Dental X-ray Examinations in the UK, 2002-2004, HPA-RPD-022, June 2007.

18) Japan DRLs 2015. http://www.radher.jp/J-RIME/report/ DRLhoukokusyoEng.pdf Accessed December 29, 2016.

19) Farman, A.G. and Farman, T.T.: A comparison of 18 different x-ray detectors currently used in dentistry. Oral Surg Oral Med Oral Pathol Oral Radiol Endod, 99 : 485-489, 2005. 